\section{Response to: 'Association between proton pump inhibitors therapy and fracture risk in patients with rheumatoid arthritis' by Lai et al}

We appreciate Lai $e a^{1}{ }^{1}$ for sharing their data and emphasising the lack of association between proton pump inhibitor (PPI) use and fracture risk in a different patient population. We agree that the adverse association found with PPI use and fracture in the previous studies has not been repeated in many other well-designed studies. Our study has tested this association for the first time in a disease state like rheumatoid arthritis (RA) where the risk of osteoporosis and fractures are already increased. ${ }^{2}$ As Lai et al emphasise our study is consistent with the prior studies in the general population that PPIs are not associated with increased fracture risk in patients with RA. However, we have to indicate that we did not evaluate different PPI doses and types which may have different risk estimates. We also agree that there is not enough evidence to recommend routine bone density testing neither for RA patients nor patients without any inflammatory disease unless they have other risk factors. Despite this, we want to emphasise that our study did not evaluate other potential health effects of PPIs in RA patients such as increased risk of community-acquired pneumonia, ${ }^{3}$ and Clostridioides difficile and other enteric infections. ${ }^{45}$ Although PPI use is quite common in RA due to common use of nonsteroidal anti-inflammatory drugs, glucocorticoids or antiplatelets, we believe that the necessity of PPIs and other medications should be regularly reviewed in RA to minimise polypharmacy and accordingly potential drug interactions and other adverse events of these medications.

\footnotetext{
Gulsen Ozen, ${ }^{1}$ Kaleb Michaud $\odot^{1,2}$

${ }^{1}$ Department of Medicine, University of Nebraska Medical Center, Omaha, Nebraska, USA

${ }^{2}$ Forward, The National Databank for Rheumatic Diseases, Wichita, Kansas, USA
}

Correspondence to Dr Kaleb Michaud, Forward, The National Databank for Rheumatic Diseases, Wichita, KS 67214, USA; kmichaud@unmc.edu
Handling editor Josef S Smolen

Contributors Both authors contributed to the writing of this response.

Funding The authors have not declared a specific grant for this research from any funding agency in the public, commercial or not-for-profit sectors.

Competing interests None declared.

Patient consent for publication Not required.

Provenance and peer review Commissioned; internally peer reviewed.

(c) Author(s) (or their employer(s)) 2020. No commercial re-use. See rights and permissions. Published by BMJ.

\section{(A) Check for updates}

To cite Ozen G, Michaud K. Ann Rheum Dis 2020;79:e157.

Received 1 August 2019

Accepted 2 August 2019

Published Online First 12 August 2019

\section{Linked}

http://dx.doi.org/10.1136/annrheumdis-2019-215982

Ann Rheum Dis 2020;79:e157. doi:10.1136/annrheumdis-2019-215992

\section{ORCID iD}

Kaleb Michaud http://orcid.org/0000-0002-5350-3934

\section{REFERENCES}

1 Lai S-W, Kuo Y-H, Liao K-F. Association between proton pump inhibitors therapy and fracture risk in patients with rheumatoid arthritis. Ann Rheum Dis 2020;79:e156.

2 Ozen G, Pedro S, Wolfe F, et al. Medications associated with fracture risk in patients with rheumatoid arthritis. Ann Rheum Dis 2019;78:1041-7.

3 Lambert AA, Lam JO, Paik JJ, et al. Risk of community-acquired pneumonia with outpatient proton-pump inhibitor therapy: a systematic review and meta-analysis. PLoS One 2015;10:e0128004.

4 HH W, Chen YT, Shih CJ, et al. Association between recent use of proton pump inhibitors and nontyphoid salmonellosis: a nested case-control study. Clin Infect Dis 2014;59:1554-8.

5 Kwok CS, Arthur AK, Anibueze Cl, et al. Risk of Clostridium difficile infection with acid suppressing drugs and antibiotics: meta-analysis. Am J Gastroenterol 2012;107:1011-9. 